\title{
Emotional Intelligence in Malaysian Police: A Review
}

\section{Kanesan, $\mathbf{P}$.}

Universiti Malaysia Sarawak, 94300 Kota Samarahan, Sarawak, Malaysia

\begin{abstract}
This article discussed the findings of previous studies on emotional intelligence in Royal Malaysia Police. Based on the review, emotional intelligence related to job stress, job satisfaction, job commitment, work-life balance, and psychological well-being of police officers. Review concludes that no significant differences in emotional intelligence by demographic factors like salary, working department, age, marital status, length of service, and job position. Police department has to organise training and seminars to enhance the emotional intelligence level of police officers. More studies have to be done on emotional intelligence in the police department, thus the findings will be helpful for the organisation's development.
\end{abstract}

Keywords: Demographic factors; Police job nature; Job stress; Royal Malaysia Police

Copyright: This is an open access article distributed under the terms of the Creative Commons Attribution-Non CommercialShare Alike 4.0 International (CC BY-NC-SA 4.0) license which permits unrestricted use, distribution, and reproduction in any medium, for non-commercial purposes, provided the original work is properly cited.

\section{INTRODUCTION}

Royal Malaysia Police (RMP) is one of our national law enforcement body, which plays an important role in maintaining national security and peace (Sazif, 2011; Yusoff, Abdullah, \& Adnan, 2017). In relation to their job scope and nature, police officers' duty demands all time preparedness in the

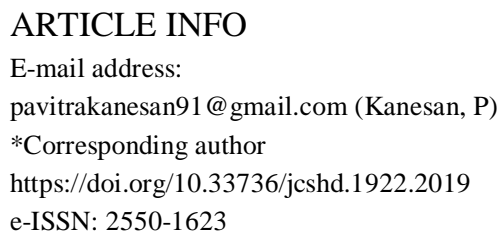

Manuscript received: 13 August 2019; Accepted:5 September 2019; Date of publication: 30 September 2019. face of any possible contingencies (Yusoff et al., 2017). Police is a stressful, challenging, high-risk as well as emotionally challenging profession.

Department of Community Health of National University of Malaysia found that police profession is the most stressful profession $(53.7 \%)$ as compared to other professions including prison officers, fire fighters, teachers, nurses, doctors, and assistant pharmacists ("Polis lebih", 2011). Masilamani et al. (2013) revealed that prevalence of stress in Malaysian police was $38.8 \%$. Masilamani et al. explained that inspectors are the backbone of an investigation team in all departments, thereby they 
are more prevalence to stress. In fact, police are under stress as they confront various situations and diverse human contact from victims to criminals (Abdullah, 2010). Abdullah (2010) expounded that the stress could be due to long working hours, less likely to get leave, on-standby call at all times, and demanding jobs bounded to cumbersome rules, regulations and instructions. Additionally, the structure and climate of RMP organisation highly emphasised on discipline and assertive are the major contributors to stress amongst police (Zaidi \& Raop, 2017). Unsurprisingly police organisation is a bureaucratic military structured organisation that foregrounded discipline (Patterson, 2009). To sum up, the work nature and organisation climate structure are the main contributors of stress amongst police officers in Malaysia.

Police is indeed a challenging profession, as they have to ensure the safety of public, as well as nation by tackling the high crime rates (Yaacob, 2012). Additionally, police officers are expected to deliver excellent services and being sensitive to the needs of the community (Abdullah, 2010). Generally, although police provide excellent service to the public, the public always perceives police officers as an enemy (Suresh, Anantharaman, Angusamy, \& Ganesan, 2013). Therefore, building a relationship with the public for effective community policing is poses as a challenge for police. Due to the myriad scope of the job itself, certain personal qualities like fair-minded, courageous, firm, patience, tolerance, and dedication are extremely required although those qualities are hard to develop (Abdullah, 2010; Alias, 2014).
Police job involves high-risk tasks (Abdullah, 2010; Patterson, 2009; Russell, 2014; Suresh et al., 2013). Police officers encounter various traumatic experiences that sandwiched them between death or life decisions (Patterson, 2009). According to Suresh et al. (2013), police profession has an adverse effect on the total life span of the police officers including their family, as they are more vulnerable to face prejudice, suspicion, and hostility from the public even during off duty. Datuk Seri Mohamad Fauzi Harun, the Director of Management Department, Bukit Aman reported that every day at least one police officer dies on duty (Kumarappa, 2014). Police officers have one of the highest rates of injuries and illnesses among all professions (Christopher et al., 2015). Particularly, junior police officers are more prone to threat as they are in the combat zone and are responsible to manage crime activities, control public safety and order, perform search, rescue, and escorting tasks (Public Service Department Malaysia, 2009). Therefore, it is common for police officers to be injured during an operation (Razali, 2018) or while helping the public (Ismail, 2018). Some unlucky one got shot by criminals (Randhawa, 2017) or attacked by public (“Latihan polis", 2017).

In fact, Williams, Ciarrochi, and Deane (2010) claimed that policing is an emotionally challenging profession and police officers experienced high depression and mental health problems as they often suppressed or failed to identify their emotions. Since, police is a highly bureaucratic military structured organisation (Patterson, 2009), rational is given more importance compared to the emotions (Putnam \& Mumby, 1993). Besides, police job nature associate with masculinity, therefore police officers mask their 
emotions (Martin, 1999) and practice higher emotional control (Daus \& Brown, 2012). Police officers feel uncomfortable to express their emotions to colleagues. In this respect, junior police officers (ranked from constables to sub-inspector) who often deal directly with the public are expected to detach their emotions when dealing with public (Martin, 1999). Consequently, hardening emotions will reduce their receptivity to understand the public's problem, which may result in less responsive behaviour (Pogrebin \& Poole, 1991). Eventually, the ability to understand others' emotions will be reduced. Besides, junior police officers have to comply with the orders of higherranking officers, regardless of their personal opinions, which may induce emotional dissonance (Yaacob, 2012). Meanwhile, senior police officers (ranked from inspector to inspector general) hold higher authority and are the backbone of investigation team. Police officers at higher power tend to be less sensitive to others' emotions (Martin, 1999). At higher levels, the police officers are expected to maintain more emotional control by manipulating their emotions which eventually reduce their ability of being sensitive toward others (Daus \& Brown, 2012). Generally, police officers practice "Silent Approach" by controlling their facial expressions in order to frighten the suspects during investigations (Arther \& Caputo, 1959). Practicing higher emotional control may eventually reduce their vulnerability to be sensitive toward others (Daus \& Brown, 2012).

As police' job nature exposed them to stressful and emotionally challenging tasks, strong emotional strength and endurance are extremely crucial (Abdullah, 2010; Baker \& Ibrahim, 2014, 2017; Yaacob, 2012). Emo- tional intelligence enables police officer to cope better with emotional demands (Baker \& Ibrahim, 2014). Salovey and Mayer (1990) defined emotional intelligence as "the ability to monitor one's own and others' emotions, to discriminate among them and to use the information to guide one's thinking and actions" (p. 189). Goleman (1995) on the other hand explained that emotional intelligence is any underlying personal characteristic that is not represented by cognitive intelligence. However, BarOn viewed emotional intelligence as noncognitive capabilities, competencies, and skills that influence an individual's ability to cope with environmental demands and pressures successfully (Bar-On, 1997). By contrast, Petrides and Furnham (2001) defined emotional intelligence as a trait and it is a constellation of emotional self-perceptions located at the lower levels of personality hierarchies. These various definitions of emotional intelligence have contributed to the development of three emotional intelligence models: (1) ability model, (2) mixed model, and (3) trait model. Generally, the existing models have categorised emotional intelligence as personal intelligence and social intelligence. Salovey and Mayer (1990) explained emotional intelligence as understanding and managing one's own (personal) and others' emotions (social). Similarly, Bar-On's mixed model of emotional intelligence included intrapersonal (personal) and interpersonal (social) dimensions (Bar-On, 1997). On the other hand, Goleman's (2001) refined mixed model also focused on self-awareness and selfmanagement (personal); social-awareness and relationship management (social). Likewise, Petrides and Furnham (2003) agreed that emotional intelligence construct is all about processing affect-stacked infor- 
mation intrapersonally (personal) and interpersonally (social). Moreover, Goleman (1995) revealed that $80 \%$ of success at work is determined by emotional intelligence and only $20 \%$ by ordinary intelligence. Furthermore, Goleman (1995) awarded emotional intelligence as the key to success at work which involves more human contact. Police profession involves more human contact (Abdullah, 2010). Thus, emotional intelligence has a significant effect on policing. This article focused past studies on emotional intelligence in RMP setting.

\section{METHOD}

A systematic review was done on several journals and postgraduate thesis on emotional intelligence of Malaysian police. The following inclusion criteria were applied: (i) published during the last 8 years (2010 2018); (ii) published in English and Bahasa Melayu; (iii) report comprising original research. Based on the criteria, there were only six studies found. Table 1 provides the details of those article or thesis reviewed.

\section{FINDINGS}

\section{Level of emotional intelligence}

Past studies have been documented that Malaysian police officers demonstrated higher emotional intelligence. To be precise, personal/intrapersonal emotional intelligence is high in police officer involved in operations; meanwhile social/interpersonal emotional intelligence is high in police of- ficers in administration. Abdullah (2010) reported that junior police officers (majority of the respondents were from operation) possessed higher level of emotional intelligence, specifically higher intrapersonal emotional intelligence. Abdullah elaborated that intrapersonal emotional intelligence enables the police officers to reduce and regulate their negative emotions, being motivated, take appropriate action by perceiving emotions accurately in order to perform their job as junior police officers that directly deal with public and in combat zone. Similarly, Yaacob (2012) reported that police officers' emotional intelligence was largely contributed by intrapersonal emotional intelligence. Yaacob also discovered that emotionally intelligent police officers focused more on positive emotions. Yaacob proposed that in order to maintain high level of emotionally intelligent, police officers have to be selective while interacting and change their perception about working environment. In contrast, Baker (2010) discovered that police officers (majority of the respondents were from administration) demonstrated higher interpersonal compared to intrapersonal emotional intelligence. Baker explained that high interpersonal emotional intelligence leads police officers to maintain a good relationship with their colleagues which eventually cultivates a sense that their working environment is productive and supportive.

\section{Emotional intelligence and demographic factors}


Emotional intelligence same across salary, Public servants have been trained to cater age, marriage status, length of service, and services to the society beyond their personal job position. Yusoff et al. (2017) found that interest and not materialistic. Abdullah there was no significant mean difference in (2010) found that no significant mean difemotional intelligence by salary categories. ferences in emotional intelligence by age

Table 1: Literature reviewed

\begin{tabular}{|c|c|c|c|c|}
\hline No & Title & Author(s) & Sample characteristic & Instrument used \\
\hline 1 & $\begin{array}{l}\text { Hubungan antara kecerdasan emosi } \\
\text { dan komitmen pekerja: Kajian di } \\
\text { kalangan pegawai polis. }\end{array}$ & Baker (2010) & $\begin{array}{l}288 \text { police officers in } \\
\text { IPD Kuching. } \\
51.4 \% \text { aged below } 36 \\
75 \% \text { married } \\
77.1 \% \text { secondary }\end{array}$ & $\begin{array}{l}\text { Kajian Kecerdasan } \\
\text { Emosi } \\
\text { (Najib, 1999) } \\
45 \text { items }\end{array}$ \\
\hline 2. & $\begin{array}{l}\text { Strategi daya tindak sebagai } \\
\text { moderator dalam hubungan antara } \\
\text { kecerdasan emosi dengan kepuasan } \\
\text { kerja, komitmen organisasi dan } \\
\text { kesejahteraan psikologi. }\end{array}$ & $\begin{array}{l}\text { Yaacob } \\
(2012)\end{array}$ & $\begin{array}{l}252 \text { police officers in } \\
\text { IPK Melaka. } \\
44 \% \text { aged below } 36 \\
75.4 \% \text { operational } \\
62.3 \%>10 \text { years service }\end{array}$ & $\begin{array}{l}\text { SRIS } \\
\text { (Schutte et al., 1998) } \\
33 \text { items }\end{array}$ \\
\hline 3 & $\begin{array}{lrr}\text { Hubungan } & \text { Kepuasan } & \text { Kerjadengan } \\
\text { Kecerdasan } & \text { Emosi } & \text { dalam } \\
\text { KalanganWarga } & \text { Polis } & \text { DiRaja } \\
\text { Malaysia. } & & \end{array}$ & $\begin{array}{l}\text { Yusoff, Ab- } \\
\text { dullah, \& } \\
\text { Adnan (2017) }\end{array}$ & $\begin{array}{l}400 \text { police officers in } \\
\text { IPD Subang Jaya. } \\
87.3 \% \text { Low-rank } \\
\text { police } \\
23.8 \text { operational } \\
29.2 \%>10 \text { years service }\end{array}$ & $\begin{array}{l}\text { Kajian Kecerdasan } \\
\text { Emosi } \\
\text { (Najib, 1999) } \\
45 \text { items }\end{array}$ \\
\hline 4 & $\begin{array}{l}\text { Kecerdasan Emosi dan Komitmen } \\
\text { Afektif: Peranan Keterikatan Kerja } \\
\text { sebagai Pengantara. }\end{array}$ & $\begin{array}{l}\text { Baker \& } \\
\text { Ibrahim } \\
(2017)\end{array}$ & $\begin{array}{l}372 \text { police officers } \\
\text { from } \\
\text { IPD/IPK Kuala } \\
\text { Lumpur, Sabah, } \\
\text { Sarawak, Selangor, and } \\
\text { Johor. } \\
\\
51.9 \% \text { aged below } 36 \\
77.4 \% \text { married } \\
57.7 \%>10 \text { years service }\end{array}$ & $\begin{array}{l}\text { WLEIS } \\
\text { (Wong \& Law 2002) } \\
16 \text { items }\end{array}$ \\
\hline 5 & $\begin{array}{l}\text { The effect of emotional intelligence } \\
\text { on police officers' work-life balance } \\
\text { The moderating role of organisational } \\
\text { support. }\end{array}$ & $\begin{array}{l}\text { Kumarasamy, } \\
\text { Pangil,\& Isa } \\
(2016)\end{array}$ & $\begin{array}{l}1566 \text { police officers } \\
\text { from } 12 \text { IPK in } \\
\text { Peninsular. } \\
77.5 \% \text { married } \\
60.6 \%>10 \text { years service } \\
12.3 \% \text { tertiary } \\
\text { education }\end{array}$ & $\begin{array}{l}\text { WLEIS } \\
\text { (Wong \& Law 2002) } \\
16 \text { items }\end{array}$ \\
\hline 6 & $\begin{array}{l}\text { Hubungan di antara kecerdasan emosi } \\
\text { dengan stress dalam kalangan } \\
\text { Anggota Unit Pasukan Gerakan Marin } \\
\text { Wilayah } 2 \text { Polis DiRaja Malaysia } \\
\text { Johor. }\end{array}$ & $\begin{array}{l}\text { Abdullah } \\
(2010)\end{array}$ & $\begin{array}{l}131 \text { police officers in } \\
\text { MOF Unit, IPK Johor. } \\
\text { All lower rank police. } \\
68.7 \% \text { aged above } 35 \\
91.0 \% \text { married } \\
83.2 \%>10 \text { yearsservice }\end{array}$ & $\begin{array}{l}\text { Kajian Kecerdasan } \\
\text { Emosi } \\
\text { (Najib, 1999) } \\
45 \text { items }\end{array}$ \\
\hline
\end{tabular}

Note: IPD:Ibu Pejabat Polis Daerah; IPK: Ibu Pejabat Polis Kontijen; MOF: Marine Operation Force; WLEIS: Wong and Law Emotional Intelligence Scale; SRIS: Self-Report Inventory Schutte. 
factor, marriage status, length of service, and job position.

Three possible phenomena could have accounted for the similarity in emotional intelligence among police officers. Hofstede, a social psychologist explained a phenomenon called process in collectivist community, which stated that employees in a collectivist community give priority for good relationship, loyalty, and conformity (Hofstede, 1980). In other words, employees in collectivist community values unity and peace, therefore, individualism is prohibited. In fact, those employees who deviated from the social norm will be stigmatised and faced prejudice. Hence, all the police officers process emotions in a standard way as they belong to collectivist community, usually by suppressing their emotions. Similarly, Durkheim's theory of collective representation stated that society influences humans' actions, behaviours, and customs in order to increase their survival need and to be a functioning member of their society (Durkheim, 1912). Thereby, police officer's emotional intelligence does not vary by demographic factors as the members maintain their actions, behaviours coherent with bureaucratic culture in order to be a functioning member of the police organisation. Such a collective nature of Malaysian community and police job nature is also relevant to Cooley's theory of looking-glass self (Cooley, 1902). Looking-glass self theory proposed that individuals tend to shape and confirm their action based on their interpersonal interaction and others perception. Individual seeks for others' approval. In this perceptive, as police officers are expected to practice higher emotional control (Daus \& Brown, 2012), they limit or feel uncomfortable to express their emotions to colleagues
(Martin, 1999). Thereby, the emotional intelligence of the police officers is same regardless of their age or length of service, although emotional intelligence is expected to increase with age or experience (Mayer \& Salovey, 1997).

\section{Emotional intelligence and job stress}

Emotional intelligence correlates with stress. Abdullah (2010) found that emotional intelligence weekly correlated to police's effects of stress. He expounded that interpersonal emotional intelligence helps them to forget the stress caused by physiological factors like tiredness.

\section{Emotional intelligence and job satisfac- tion}

Yaacob (2012) and Yusoff et al. (2017) found a significant positive relationship between emotional intelligence and job satisfaction. Furthermore, Yaacob (2012) claimed that intrapersonal emotional intelligence significantly predicts job satisfaction. As they understand and perceive their own emotions accurately, they can regulate their emotions to be proactive in order to perform a task well. Thus, they satisfied with their job. Furthermore, police officers with high intrapersonal emotional intelligence could eventually cultivates a belief in them to have a control over the task assigned thus, satisfied with the job. Interestingly, police officers less likely use their emotions to facilitate thinking while facing challenges. In other words, they focused more on problem-solving coping style while confronting challenges thus, satisfied with the job. However, Yusoff et al. (2017) reported that job satisfaction was highly correlated with interpersonal emotional intelligence. Higher interpersonal emotional intelligence culti- 
vates empathy in them and enhances their tolerance level as they can understand and accept others' emotions. Therefore, they feel satisfied with the job.

In fact, both intrapersonal and interpersonal emotional intelligence related to job satisfaction. However, which emotional intelligence is more related to job satisfaction is depends on the department they worked. Most of the samples in Yaacob (2012) were from the operational department where they exposed to high level of stress, high risked job tasks. Whether they like or not they have to follow the order and perform. Thus, their intrapersonal emotional intelligence highly related to their job satisfaction. Meanwhile, a majority of the sample in Yusoff et al. (2017) were from administration department where they less likely exposed to threat. They work in an office and deal with documents most of the time. Thus, their interpersonal emotional intelligence highly relates to their job satisfaction.

\section{Emotional intelligence and job commit- ment}

Emotional intelligence correlated to job commitment (Baker, 2010; Baker \& Ibrahim, 2017; Yaacob, 2012). Yaacob (2012) found that intrapersonal emotional intelligence significantly predicts job commitment despite the organisational factors. High intrapersonal emotional intelligence enhances their ability to evaluate their emotional experiences accurately and built their confidence about their emotional skills like understanding, perceiving, managing, and regulating emotions. Additionally, Yaacob revealed that emotional intelligence was highly correlated with continuing commitment compared to affective and normative commitments. Police who have high emotional intelligence wished to stay in organisations because they believe their salary will increase and not willing to lose retirement benefits. Baker and Ibrahim (2017) also agreed that intrapersonal emotional intelligence highly related to affective commitment. In contrast, Baker (2010) revealed that there was a strong relationship between job commitment and interpersonal emotional intelligence. In this perceptive, as their interpersonal emotional intelligence is high, it leads them to have a good relationship with other colleges. They develop a sense that their working environment is productive and supportive. Thus, they are highly committed to their job.

This shows that interpersonal emotional intelligence correlates more with job commitment if working environment is supportive and the relationship with their colleagues is good. Meanwhile, intrapersonal emotional intelligence correlates more with job commitment as an individual have the ability to identify and use their emotions effectively despite the organisational factor.

\section{Emotional intelligence and work-life bal- ance}

Emotionally intelligent police can balance their personal and professional life as they have the ability to influence other people using their emotions. So, high emotional intelligence enables them to work effectively and thus maintain their work-life balance. Kumarasamy et al. (2015) stated that emotional intelligence highly related to worklife balance over work overload, job engagement, organisational support, and technology advancement. This is because emotional intelligence helps an individual to 
understand their own emotions as well as others' emotions and to express their emotions appropriately. The high emotional intelligence influences their interaction with their colleagues by promoting a better communication. As a result, they can complete their work effectively and maintain their work-life balance. In addition, emotionally intelligent individuals tend to be balanced, matured and retain a positive viewpoint almost all the time. Therefore, they can encounter all the threads in their personal and professional life. Moreover, those with high emotional intelligence able to rediscover themselves, feel motivated, develop empathy, have good communication with their co-workers, allocate time for their family and also builds a good relationship with their spouse.

\section{Emotional intelligence and psychological well-being}

Yaacob (2012) found that emotional intelligence moderately correlates with psychological well-being of police officers and perception of emotions significantly predicts the psychological well-being. Those police officers with high emotional intelligence will have high psychological well-being. This is because high emotional intelligence enables them to maintain a positive mental attitude as they have the ability to regulate their emotions effectively. In this perceptive, those with high emotional intelligence tend to enhance pleasant or positive emotions rather than focusing on unpleasant emotions. Therefore, emotionally intelligent individuals will cultivate their positive emotions to think positively. i. All the previous studies findings were based on quantitative approach using survey method. Therefore, it is highly recommended to employ qualitative approaches like interview to understanding the underlying relationship between the variables measured.

ii. RMP launched Integrity Plan 20162020 to achieve the ultimate aim of providing world-class policing service to the society (Bakar, 2016). In addition, according to previous Inspector General of Police Tan Sri Khalid Abu Bakar practising integrity is paramount in the police force. However, according to the statistic of Enforcement Agency Integrity Commission, the highest complaint was reported on RMP and the numbers of complaints increased drastically from 18 complaints in 2011 to 440 in 2017 (Enforcement Agency Integrity Commission, 2018). In a study by Aremu, Pakes, and Johnston (2011), found that emotional intelligence act as a catalyst in promoting integrity-based policing in Nigeria. Therefore, it is recommended to study the relationship between emotional intelligence and integrity in Malaysian setting. Hence, the findings could be beneficial to enhance the integrity in our police.

iii. Further studies on emotional intelligence can focus on its relationship with motivation, job performance, job stress, job competencies like leadership skills, problem-solving skills, resilience interpersonal skills aspects.

\section{RECOMMENDATIONS FOR FUTURE RESEARCH}




\section{CONCLUSION}

Studies on emotional intelligence in Malaysian Police setting are very few and more studies have to be done. Police is a stressful, high risked and challenging profession. The police officers will dwell into bundles of emotions. Therefore, police officers need to enrich their emotional intelligence, as emotional intelligence enhances a person's capacity to perceive, express, understand, use, and manage emotions in oneself and other people which lead to adaptive behaviour. The analysis concludes that the emotional intelligence does not varied by demographic factors like salary, working department, age, marital status, service period and job position. Previous studies found that emotional intelligence related to police stress, job commitment and satisfaction. Job stress, job satisfaction and job commitment are the contributors to job performance. Therefore, the RMP is strongly encouraged to conduct seminars, workshops on emotional intelligence in order to enrich the police officers' emotional intelligence level. It will be helpful for RMP to achieve their mission to produce world-class policing by 2020. Furthermore, emotional intelligence was found to have significant relationship with worklife balance and psychological well-being of police officers. Therefore, cultivating emotional intelligence in police will enhance their subjective well-being. They will be happy and satisfied with their life as they can balance their work and personal life in addition to psychological well-being.

\section{REFERENCES}

Abdullah. (2010). Hubungan di antara kecerdasan emosi dengan stress dalam kalangan anggota unit Pasukan
Gerakan Marin Wilayah 2 Polis DiRaja Malaysia Johor (Master's thesis). Universiti Teknologi Malaysia, Skudai, Johor.

Alias, L. M. (2014). Hubungan pengurusan menangani jenayah dengan kompetensi pegawai dan anggota polis dengan: Di Ibupejabat Polis Daerah Kulaijaya, Johor (Master's thesis). Universiti Teknologi Malaysia, Skudai, Johor.

Aremu, A. O., Pakes, F., \& Johnston, L. (2011). The moderating effect of emotional intelligence on the reduction of corruption in the Nigerian police. Police Practice and Research, 12(3), 195-208. doi:10.1080/15614263.2010.536724

Arther, R., \& Caputo, R. (1959). Interrogation for investigators. New York, NY: William C. Copp\& Associates.

Bakar, K. A. (2016, August 13). Memperkasakan PDRM. Harian Metro. Retrieved from https://www.hmetro. com.my/node/158606

Baker, R. (2010). Hubungan antara kecerdasan emosi dan komitmen pekerja: Kajian di kalangan pegawai polis (Master's thesis). Universiti Malaysia Sarawak, Kota Samarahan, Sarawak.

Baker, R., \& Ibrahim, H. I. (2014). Tekanan kerja dalam organisasi kepolisan: Tinjauan dalam perspektif kecerdasan emosi. Jurnal Kemanusiaan, 23, 1-24.

Baker, R., \& Ibrahim, H. I. (2017). Kecerdasan emosi dan komitmen afektif: Peranan keterikatan kerja sebagai pengantara. Jurnal Pengurusan, 49, 103-115. 
Bar-On, R. (1997). The Emotional Quotient inventory (EQ-i): A test of emotional intelligence. Toronto, Canada: MultiHealth Systems.

Christopher, M. S., Goerling, R. J., Rogers, B. S., Hunsinger, M., Baron, G., Bergman, A. L., \& Zav, D. T. (2015). A pilot study evaluating the effectiveness of a mindfulness-based intervention on cortical awakening response and health outcomes among law enforcement officers. Journal of Police and Criminal Psychology, 31(1), 15-28. doi:10.1007/s11896 015-9161-x

Cooley, C. H. (1902). Human nature and the social order. New York, NY: C. Scribner's sons.

Daus, C. S., \& Brown, S. G. (2012). The emotion work of police. In N. M. Ashkanasy, C. E. J. Hartel, \& W. J. Zerbe (Eds.), Research on emotions in organizations (pp. 305-328). Bingley, England: Emerald Group.

Durkheim, E. (1912). The cultural logic of collective representations. In $\mathrm{C}$. Lemert (Ed.), Social theory the multicultural and classic readings (pp. 9099). Boulder, CO: Westview press.

Enforcement Agency Integrity Commission. (2018). The numbers of complaints registered for the year 2011 to 2018. Retrieved from http://www.eaic.gov.my/en/pusatsum ber/statistik/complaints

Goleman, D. (1995). Emotional intelligence: Why it can matter more than IQ for character health and lifelong achievement. New York, NY: Bantam Books.
Goleman, D. (2001). An EI-based theory of performance. In C. Cherniss\& D. Goleman (Eds.), The emotionally intelligent workplace: How to select for, measure, and improve emotional intelligence in individuals, groups, and organizations (pp. 27-44). San Francisco, CA: Jossey-Bass.

Hofstede, G. (1980). Culture's consequences: International differences in work related values. Beverly Hills, CA: Sage.

Ismail, I. S. (2018, January 3). 2 polis cedera ketika bantu baiki kereta rosak. Berita Harian. Retrieved from https://www.bharian.com.my/berita/k es/2018/01/370362/2-polis-cederaketika-bantu-baiki-kereta-rosak

Kumarappa, K. M. (2014, June 29). Seorang maut setiap hari: Anggota polis terdedah kepada risiko dan ancaman setiap saat ketika bertugas. Harian Metro. Retrieved from https://m.facebook.com/PolisDirajaM alaysia/photos/a.885400741470234.10737 4255.161086313901684/8067654626 $67096 /$ type $=1$

Kumarasamy, M. M., Pangil, F., \& Isa, M. F. M. (2015). Individual, organisational and environmental factors affecting work-life balance. Asian Social Science, 11(25), 111-123. doi:10.5539/ass.v11n25p111

Latihan polis PRU14: Kedah panas, rusuhan di Perak, Johor hangat. (2017, December 15). Malaysia Kini. Retrieved from https://www.malaysiakini.com/news/ 405628 
Martin, S. (1999). Police force or police service? Gender and emotional labor. The Annals of the American Academy of Political and Social Science,561, 111-126.

Masilamani, R., Bulgiba, A., Chinna, K., Darus, A., Isahak, M., Kandiben, S., \& Koh, D. (2013). Prevalence and associated factors of stress in the Malaysian police force. Preventive Medicine, 57, S57-S59. doi:10.1016/j.ypmed.2013.01.00

Mayer, J. D., \& Salovey, P. (1997). What is emotional intelligence? In P. Salovey \& D. Sluyter (Eds.), Emotional development and emotional intelligence: Implications for educators (pp. 3-31). New York, NY: Basic Books.

Patterson, G. T. (2009). Mental stress and workers' compensation claims among police officers. Journal of Workplace Rights, 14(4), 441-455. doi:10.2190/WR.14.4.d

Petrides, K. V., \& Furnham, A. (2001). Trait emotional intelligence: Psychometric investigation with reference to established trait taxonomies. European Journal of Personality, 15(6), 425448. doi:10.1002/per.416

Petrides, K. V., \& Furnham, A. (2003). Trait emotional intelligence: Behavioural validation in two studies of emotion recognition and reactivity to mood induction. European Journal of Personality, $\quad 17, \quad 39-57$. doi:10.1002/per.466

Pogrebin, M. R., \& Poole, E. D. (1991). Police and tragic events: The management of emotions. Journal of
Criminal Justice, 19(4), 395-403. doi:10.1016/0047-2352(91) 90036-u

Polis lebih stress berbanding guru. (2011, September 27). Berita Harian. Retrieved from http://www.bharian.com. my/bharian/articles/Polislebihstresber bandingguru/Article?bcsi_ scan_A734CB6DCD13BCFC $=0$

Public Service Department Malaysia. (2009). Pekeliling perkhidmatan bil.25/2009 perubahan skim perkhidmatan pegawai kanan polis dan pegawai rendah polis dan konstabel. $\mathrm{Pu}-$ trajaya: Public Service Department Malaysia. Retrieved from https://sistem.jpa.gov.my/ppspp/i ndex.php/skimperjawatan/item/1027perubahanskimperkhid matanpegawai-kanan-polisdanpegawai-rendah-polis-dan konstabel.html

Putnam, L. L., \&Mumby, D. K. (1993). Organizations, emotion and the myth of rationality. In S. Fineman (Ed.), Emotion in organizations (pp. 36-57). Thousand Oaks, CA: Sage.

Randhawa, S. S. (2017, August 19). Police detective shot dead in Kedah. The Star. Retrieved from https://www.thestar.com.my/news/nat ion/2017/08/19/police-detective-shotdead-in-kedah/

Razali, S. A. (2018, February 19). Syukur hanya cedera ringan. Harian Metro. Retrieved from https://www.hmetro.com.my/ mutakhir/2018/02/314270/syukur-hanyacedera-ringan 
Russell, L. M. (2014). An empirical investigation of high-risk occupations: Leader influence on employee stress and burnout among police. Management Research Review, 37(4), 367384. doi:10.1108/mrr-10-2012-0227

Salovey, P., \& Mayer, J. D. (1990). Emotional intelligence. Imagination, $\mathrm{Cog}$ nition and Personality, 9(3), 185-211. doi:10.2190/dugg-p24e-52wk-6cdg

Sazif, M. M. S. (2011). The Stress Effect Towards PDRM Personnel: A Case Study on

Suresh, R. S., Anantharaman, R. N., Angusamy, A., \& Ganesan, J. (2013). Sources of job stress in police work in a developing country. International Journal of Business and Management, 8(13), 102-110. doi:10.5539/ijbm.v8n13p102

Williams, V., Ciarrochi, J., \& Deane, F. P. (2010). On being mindful, emotionally aware, and more resilient: Longitu- dinal pilot study of police recruits. Australian Psychologist, 45(4), 274282.

doi:10.1080/00050060903573197

Yaacob, M. (2012). Strategi daya tindak sebagai moderator dalam hubungan antara kecerdasan emosi dengan kepuasan kerja, komitmen organisasi dan kesejahteraan psikologi (Master's thesis). Universiti Teknologi Malaysia, Skudai, Johor.

Yusoff, E. Y. C., Abdullah, H. M. Z., \& Adnan, Z. H. (2017). Hubungan kepuasan kerja dengan kecerdasan emosi dalam kalangan warga Polis Diraja Malaysia. Malaysia Journal of Society and Space, 13(1), 22-37.

Zaidi, N. Y. M., \&Raop, N. A. (2017). Faktor-faktor yang mempengaruhi tekanan kerja dalam kalangan anggota polis: Satu kajian di Kem Batalion 9 PGA Kuala Terengganu. Jurnal Sains Sosial, 2 , 103-116. 